\title{
KNOWLEDGE MANAGEMENT DALAM PENGELOLAAN KEUANGAN DAERAH
}

\author{
M.R. Khairul Muluk*)
}

Abstract

Pada dasarnya Manajemen keuangan daerah yang mandiri berasal dari desentralisasi fiskal yang dilimpahkan kewenangannya oleh pemerintah pusat sebagai bagian yang dibutuhkan bagi desentralisasi politik. Manajemen keuangan daerah akan menyangkut dua hal pkok, yaitu pendapatan dan pengeluaran.

Ter.edapat beberapa masalah yang dihadapi daerah dalam mengelola keuangannya. Untuk mengatasi masalah tersebut dan untuk meningkatkan kemandirian daerah di masa yang akan dat.aing, maka seyogyanya daerah berpaling pada pendekatan resource-based, yakni sebuah pendekatan yang mendasarkan diri pada kekuatan dan potensi internal untuk memenangkan persaingan. Kini, pendekatan sumber daya ini berkembang melalui very intangible resource, yakni pengetahuan, sebagai suatu kekuatan utama. Kemampuan mengelola pengetahuan ini akan memunculkan kemampuan inivasi bagi organisasi. Inovasi inilah yang pada saat ini diyakini sebagai sumber bagi keunggulan bersaing.

Jika sebuah daerah Mampu mengelola pengetahuan sehingga memiliki kemampian inti, maka daerah tersebut diyakini akan Mampu menyelesaikan persoalannya dan Mampu menciptakan keuanggulan bersaing. Dengan demikian, tentu pelayanan public yang diterima oleh masyarakat akan semakin memuaskan dan kemandirian daerah dalam mengelola massalah dan kebutuhannya sendiri akan terpenuhi.

Key words: knowledge management, resource-based, very intangible resource, innovation 


\section{PENDAHULUAN}

Desentralisasi fiskal berkaitan erat dengan devolusi (Manor, 1999; Humes IV, 1991; MacKintosh \& Roy, 1999; Fiscal Policy Resource Center, 2001). Desentralisasi fiskal, yang berarti pemerintah atasan menyerahkan pengaruh atas keputusan anggaran dan pengeluaran kepada pemerintah bawahan, seharusnya didahului oleh adanya desentralisasi politik. Desentralisasi fiskal tanpa desentralisasi politik maka sulit mewujudkan adanya desentralisasi sejati yakni desentralisasi yang benar-benar mampu mencerminkan kepentingan dan aspirasi daerah. .Ddesentralisasi fiskal membutuhkan adanya akuntabilitas terhadap masyarakat dan lembaga di daerah ketimbang terhadap atasan di luar daerah. Sebaliknya, devolusi juga membutuhkan adanya desentralisasi fiskal untuk menopang kemandirian pemerintah daerah dalam mengatur dan mengurus fungsifungsi yang diembannya. Ada tiga sumber daya yang harus mampu dikelola oleh pemerintah daerah guna mencapai tujuan yang telah ditentukan, yakni pengelolaan atas pegawai dan keuangan, serta adanya dukungan politik.

Kemampuan pemerintah daerah untuk menyediakan layanan publik yang efektif sangat tergantung pada kemampuan keuangannya (Humes IV, 1991, 235). Tanpa uang, pemerintah daerah tidak dapat membayar pegawai, perlengkapan dan peralatan, serta berbagai kontrak penyediaan layanan lokal, dan lain sebagainya. Desentralisasi fiskal dan devolusi tampak seperti dua sisi yang berbeda dari satu koin mata uang yang sama sehingga desentralisasi fiskal menuntut adanya devolusi, dan begitu pula sebaliknya. Dalam kerangka devolusi inilah, maka desentralisasi fiskal berkaitan dengan dua hal pokok, yakni kemandirian daerah dalam memutuskan pengeluaran guna menyelenggarakan layanan publik dan memenuhi kebutuhan publik, dan kemandirian daerah dalam memperoleh pendapatan untuk membiayai pengeluaran tersebut (Norton, 1994 : 71-2; Smith, 1985 : 99-109). Manajemen keuangan daerah yang efektif pada dasarnya berkaitan dengan pengelolaan dua hal tersebut yakni pendapatan dan pengeluaran daerah. 


\section{Beberapa Masalah Manajamen Keuangan Daerah}

Terdapat beberapa masalah pengelolaan keuangan dalam jangka panjang. Beberapa fenomena ini tampak memberikan hasil yang seakan memuaskan dalam jangka pendek namun beresiko krisis pada masa yang akan datang. Ada dua segi fenomena ini, yakni yang menyangkut penerimaan maupun pengeluaran. Dari segi penerimaan, ada tiga jenis yang memperihatinkan.

Pertama, terlalu bergantungnya pemerintah daerah pada dana transfer dari Pemerintah Pusat, baik itu yang berupa Dana Alokasi Umum maupun Dana Alokasi khusus. Fenomena yang berkaitan dengan jenis ini tampak dari upaya banyak pejabat Pemda untuk melakukan lobbi ke pejabat berwenang di Departemen Keuangan agar menambah porsi dana transfer bagi daerahnya. Cara ini dilakukan dengan menyusun kembali rumusan yang akan dikenakan bagi daerahnya sehingga besarnya dana transfer meningkat. Upaya ini tentu dilakukan tidak secara formal bersifat di bawah tangan dan tersedia dana tersendiri yang disediakan untuk proses ini. Untuk melakukan cara ini, seringkali Kepala Daerahnya yang melakukan lobi sendiri atas sepengetahuan DPRD setempat. Wajar kiranya jika ada beberapa Bupati lebih banyak berada di Jakarta ketimbang berada di daerahnya sendiri.

Kedua, upaya untuk meningkatkan penerimaan melalui Pendapatan Asli Daerah diintensifkan dengan menambah jumlah biaya dan ragamnya baik yang berupa pajak daerah maupun retribusi. Sebenarnya upaya seperti ini sangat baik untuk meningkatkan kemandirian daerah dan mengurangi ketergantungannya pada pemerintah pusat. Namun bila hal ini dilakukan secara tidak cermat dan sewenang-wenang dengan mengeluarkan sekian banyak peraturan daerah untuk melegalisasi begitu banyak pungutan tanpa perhitungan yang tepat bagi kemaslahatan masyarakat dan kepentingan jangka panjang pemerintahan daerah maka akan menimbulkan beragam dampak negatif. Dalam jangka pendek hal ini memicu ketidak-puasan publik, memicu biaya hidup tinggi, dan mengurangi daya tarik investasi. Pada akhirnya, jenis ini justru menurunkan kualitas layanan publik yang seharusnya menjadi lebih baik karena ada desentralisasi. 
Ketiga, fenomena yang terjadi di banyak daerah di luar Jawa, terutama di daerah yang kaya akan sumber daya alam. Banyak kabupaten yang terlalu bergantung pada penerimaan yang bersumber pada eksplorasi sumber daya alam semata. Dalam jangka panjang tentu ini sangat berbahaya karena beberapa hal. Sumber daya alam bersifat tidak dapat diperbaharui dan pasti habis dalam jangka waktu tertentu. Tidak ada sumber daya alam yang kekal. Banyak kasus di dunia ini yang menunjukkan munculnya kota mati begitu bahan tambang telah habis tergali di kota tersebut. Tentu hal ini tidak dikehendaki oleh masyarakat setempat dan Indonesia pada umumnya karena akan menimbulkan beban berat yang harus dipikul bersama nantinya. Terlalu bergantung pada sumber daya alam akan memicu eksplorasi yang berlebihan. Karena sumber daya alam strategis dikelola negara, maka sebenarnya daerah bergantung pada pemerintah pusat melalui dana perimbangan. Selain itu, eksplorasi sumber daya alam berlebih biasanya tidak diikuti oleh tindakan-tindakan yang bersifat mencegah kerusakan lingkungan. Tentu hal ini akan berdampak pada kerusakan rantai ekologis yang akan mempengaruhi tidak saja masyarakat setempat tetapi mempengaruhi pula masyarakat lainnya pada area yang lebih luas. Jika bencana alam timbul maka hilanglah jerih payah pembangunan yang dilakukan dalam waktu sebelumnya yang memakan biaya, tenaga, dan pengorbanan lainnya.

Dari segi pengeluaran, terdapat dua fenomena negatif yang tidak bermanfaat dalam jangka pendek dan bahkan berbaha ya bagi pemerintahan daerah dalam jangka panjang. Fenomena tersebut berupa pemborosan baik yang bersifat struktural maupun perilaku. pemborosan struktural tercermin dalam habisnya anggaran daerah sebagian besar karena biaya rutin yang disebabkan oleh terlalu gemuknya birokrasi hanya untuk sekedar 'menyenangkan pejabat lokal' ketimbang kebutuhan riil masyarakat untuk memperoleh layanan publik. Sudah menjadi rahasia umum jika banyak pemerintah daerah memiliki struktur organisasi yang tidak efisien dan hanya sekedar memberi tempat bagi banyak pejabat yang terpangkas jabatannya atau dilimpahkannya banyak pegawai pusat ke daerah. Semakin gemuk birokrasi lokal maka ia membutuhkan anggaran yang semakin besar untuk 'menghidupinya'. Kondisi ini tentu tidak kondusif bagi 
pelayanan publik karena seringkali kegiatan yang diselenggarakan dinas tertentu hanya sekedar ada aktivitas, bukannya didasarkan pada aktivitas yang dibutuhkan oleh mas yarakat.

Pemborosan struktural lainnya adalah berkaitan dengan upaya mengembangkan sumber daya aparat lokal. Banyak daerah kini mengalokasikan dana bagi pendidikan SDMnya. Sayangnya, dana ini seakan menguap begitu saja karena banyak pegawai yang disekolahkan baik pada tingkatan sarjana maupun magister dan bahkan doktor pada institusi pendidikan yang tidak begitu jelas kualitas dan reputasinya. Kini banyak program pendidikan yang digelar di daerah tanpa kontrol kualitas yang memadai dari pemerintah. Bahkan banyak insitusi yang melakukan 'jual beli gelar' terselubung. Dana masyarakat menjadi tidak bermanfaat karena pendidikan yang dibiayai pemda ini tidak didesain dengan cermat mengenai kualitas dan kualifikasi yang dibutuhkan. Apa sebenarnya potensi daerah sehingga dibutuhkan SDM macam apa juga tidak diperhitungkan dengan tepat. Jika hal ini berlarut-larut maka akan menjadi tidak jelas pemanfaatan SDM yang ada. Setelah banyak pegawai yang bergelar lalu mereka akan menuntut adanya penyesuaian pangkat dan jabatan. Hal ini tentu memiliki konsekuensi anggaran pula. Tidak ada efek kemajuan potensi daerah yang timbul, bahkan akan memicu semakin kuatnya gejala formalisme di daerah. Jelas hal ini bukan fenomena positif bagi pemerintahan daerah yang berorientasi pada kualitas layanan publik dan kemandirian daerah.

Selain itu, ada pula pemborosan yang berkaitan dengan perilaku perangkat daerah, baik itu yang menggejala di birokrat lokal maupun di politisi lokal yang ada di DPRD. Pemborosan ini menyangkut perilaku menyimpang karena rendahnya kontrol dalam pemerintahan daerah. kini pemerintah pusat memiliki kontrol tak langsung kepada daerah dan pada saat yang sama tidak ada kontrol masyarakat yang melembaga. Akibatnya birokrat lokal dikontrol sangat kuat oleh DPRD, tetapi DPRD tidak dikontrol oleh lembaga apapun diluarnya yang berkenaan dengan manajemen keuangan daerah. Jika pemborosan perilaku muncul dari anggota DPRD maka akan sulit untuk dikendalikan secara melembaga selain oleh anggota DPRD yang lain. Jika terjadi prinsip 'tahu sama 
tahu' maka tidak ada lagi yang bisa diperbuat masyarakat. Fenomena ba nyaknya DPRD yang meningkatkan kesejahteraan dirinya secara individual yang dilembagakan melalui APBD tak dapat ditolak oleh masyarakat. Fenomena makelar proyek dan intervensi informal atas berbagai aktivitas penyelenggaraan pelayanan publik sudah menjadi pengetahuan umum. Jika hal ini terus berlangsung maka tak diragukan lagi betapa buruknya masa depan masyarakat dalam menerima layanan pemerintah daerah.

Jika dana yang ada saat ini tidak dimanfaatkan dengan baik maka dalam jangka panjang kita akan kehilangan peluang untuk memperbaiki kemampuan daerah dalam membangun dan memenuhi kebutuhannya sendiri. Kekhawatiran ini menjadi begitu kuat karena pintu globalisasi telah terbuka lebar. Ia akan merasuk ke daerah-daerah dan mengalahkan beragam potensi daerah untuk berkembang. Selain itu, dinamika internal dalam skala lokal dan nasional juga telah berkembang sedemikian pesat. Untuk mengatasi hal ini perlu perubahan strategis yang diikuti oleh kesadaran bersama segenap komponen bangsa dan terutama perangkat daerah akan arti pentingnya manajemen keuangan daerah yang dilakukan saat ini akan berpengaruh pada kemampuan dan kesejahteraan di masa depan.

\section{Pengembangan Ke mampuan Inti Pemerintahan Daerah}

Pemaparan berbagai masalah yang dihadapi daerah dalam manajemen keuangannya telah menyadarkan kita bahwa mengelola tanggung jawab pengambilan keputusan dalam pendapatan dan pengeluaran jelas bukan suatu hal yang mudah bagi pemerintah daerah. Dalam prakteknya, pemerintah daerah menghadapi dua aspek penting, yakni aspek kelembagaan yang sangat berkaitan dengan kapasitas daerah baik dalam mengelola pendapatan maupun pengeluaran, dan aspek pertumbuhan pengeluaran yang tidak diimbangi dengan kapasitas yang memadai. Hal ini justeru memicu ketergantungan finansial yang lambat-laun semakin kuat terhadap pemerintah pusat dan mengurangi kualitas penyelenggaraan desentralisasi politik. 
Berbagai aspek kelembagaan di daerah yang harus diperhatikan oleh pemerintah daerah maupun pemerintah pusat mencakup tiga hal (Bird, 2000 : 2331), yakni : kapasitas daerah, akuntabilitas dan informasi, serta transparansi fiskal. Jika daerah tidak memiliki kemampuan kelembagaan yang memadai maka kondisi ini akan mengurangi derajat kemandirian daerah dalam menyelenggarakan local self-governance.

Arti penting kemampuan kelembagaan ini tidak hanya disadari untuk sektor publik saja, bahkan sektor bisnis telah mengembangkannya dengan begitu cepat dan maju karena kerasnya persaingan dan cepatnya perubahan lingkungan. Ada dua pendekatan dasar mengenai pengembangan kemampuan ini, yakni market-based dan resource-based. Huseini (1999) mengungkapkan bahwa dewasa ini ada pergeseran dari pendekatan market-based menuju resource-based, dalam menyusun kemampuan organisasi.

Dalam banyak hal, para pejabat di Indonesia seringkali salah tafsir terhadap makna pendekatan sumber daya (resource) ini. Mereka selalu mengkaitkan istilah sumber daya dengan sumber daya alam, sehingga resourcebased dimaknai sebagai pemanfaatan sumber daya alam. Tentu pemahaman ini meredusir makna yang terkandung dalam istilah resource dan dapat menjerumuskan perumusan strategi penyelenggaraan pemerintahan daerah dalam makna yang begitu sempit sehingga dapat menimbulkan masalah seperti yang telah dijelaskan diatas. Sebenarnya pendekatan kedua tersebut bisa ditelusuri dalam tiga strategic resources dalam organisasi, yakni tangible resources, intangible resources, dan very intangible resources. Ketiga sumber daya tersebut akhirnya sama-sama bermuara pada pengetahuan (knowledge).

Senada dengan pandangan ini telah dikemukakan oleh Barton (1995) yang menyimpulkan bahwa lingkungan yang berubah dengan cepat dan yang akan berlangsung terus di masa depan harus direspons dan dihadapi dengan mencari stabilitas yang mendasari ketidakpastian yang terjadi. Stabilitas ini terletak pada pengetahuan yang dimanifestasikan dalam kemampuan inti (core capabilities).

Gagasan mengenai pentingnya kemampuan inti ini sebenarnya pernah mengemuka di Indonesia ketika Huseini menyodorkan konsep SAKA SAKTI 
(satu kabupaten-satu kompetensi inti). Surabaya dan Padang juga pernah memiliki program yang mirip dengan gagasan ini dengan meniru apa yang pernah diterapkan di Jepang melalui program One Village, One Product Movement. Apa yang diterapkan di kedua daerah tidak terlalu berhasil karena tidak berorientasi pada kemampuan melainkan pada produk akhirnya saja (Huseini, 1999). Pada masa kepemimpinan Gubernur Basofi Sudirman, Jawa Timur juga pernah memperluas gagasan ini melalui Gerakan Kembali ke Desa (GKD). Namun, hasilnya lebih tampak sebagai slogan pembangunan ketimbang manfaat yang diterima oleh masyarakat. Sehingga dapat dipahami jika desa-desa di Jawa Timur kini tidak jelas kemampuannya dan produknyapun tidak dapat bersaing dalam pasar regional dan global.

Selanjutnya, untuk memperjelas posisi pendekatan resource-based ini maka akan dipaparkan dua hal penting, yakni cakupan makna dari pengetahuan dan jenjang pencapaian kemampuan inti. Selanjutnya akan dibahas serangkaian aktivitas dalam mengembangkan dan menyebarkan pengetahuan sehingga dapat mencapai kemampuan inti.

Terminologi pengetahuan seringkali dijumbuhkan dengan data dan informasi. Jika tidak diperjelas perbedaannya, maka akan mengakibatkan kebingungan yang terus berkembang karena pemanfaatannya akan tumpang tindih dengan banyak disiplin ilmu yang terfokus pada aras data dan informasi. Dengan mengacu pada pandangan Davenport, Prusak, dan Peter Drucker, perbedaan antara data, informasi, dan pengetahuan dijelaskan dengan sangat baik oleh Zolingen, Streumer, dan Stooker (2001). Data merupakan sekumpulan fakta tentang kejadian yang bersifat obyektif dan diskret.

Sementara informasi adalah data yang dilengkapi dengan relevansi dan tujuan. Data berubah menjadi informasi ketika seseorang memberi makna terhadap data. Ketika seseorang menyampaikan makna tersebut, dari sudut pandangnya, berarti ia telah mentransmisikan informasi. Seseorang disebut membicarakan pengetahuan ketika informasi telah mendapat tempat dalam kerangka acuan pengguna sehingga pengguna tersebut menghubungkan tindakannya dengan kerangka acuan tersebut. 
Buckley \& Carter (2000) lebih menyukai pandangan yang mengungkapkan bahwa data, informasi, dan pengetahuan merupakan suatu hierarki yang meningkatkan makna, kedalaman, dan relevansi terhadap tindakan. Informasi merupakan data yang ditafsirkan, dengan makna yang tidak dimiliki oleh data sederhana. Sementara pengetahuan merupakan informasi terstruktur, yang mengungkap keterkaitan, wawasan dan generalisasi, yang tidak dimiliki oleh informasi yang sederhana.

Istilah pengetahuan (knowledge) yang semula dipahami oleh para filosof barat (dimotori oleh Plato) adalah justified true beliefs. Namun demikian, Nonaka dan Takeuchi mengkritik konsep tersebut sebagai terlalu rasional dan berasal dari proses mental ideal yang mengenyampingkan hasil pengalaman inderawi. Konsep tersebut gagal dalam menyentuh dimensi pengetahuan yang bersifat relatif, dinamis, dan humanistis (Nonaka, Toyama, \& Konno, 2000). Konsep Barat tersebut hanya mengakui pengetahuan yang bersifat eksplisit, sementara pengetahuan pada saat yang bersamaan juga mencakup tacit knowledge. Tacit berarti sesuatu yang tidak dengan mudah dilihat dan diekspresikan. Ia berakar dalam tindakan dan pengalaman pribadi, seperti halnya dambaan, nilai, ataupun emosi. Wawasan dan intuisi subyektif juga masuk dalam kategori ini. Pengetahuan tacit sangat bersifat pribadi dan sulit diformalisasikan (Nonaka dan Takeuchi, $1995: 8-21$ ).

Davenport dan Prusak (dalam Zolingen, Streumer, dan Stooker, 2001) mengungkapkan bahwa pengetahuan bersifat personalized dan dipengaruhi oleh banyak hal. Ia merupakan ramuan cair dari pengalaman berkerangka, nilai, informasi kontekstual, wawasan ahli yang memberikan kerangka kerja untuk mengevaluasi dan menggabungkan pengalaman baru dan informasi. Dalam organisasi, pengetahuan seringkali melekat tidak hanya di dalam dokumen, tetapi juga rutinitas, proses, praktek, dan sekaligus norma keorganisasian. Dalam hal ini ada pengakuan bahwa pengetahuan merupakan realitas yang dikonstruksi secara sosial, dipengaruhi oleh kepercayaan dan nilai pribadi, ditempa dalam irama sehari-hari, dan dapat dilihat dari produk dan jasa organisasi. Dengan demikian, pengetahuan memanglah rumit karena bersifat perorangan, sehingga 
menyulitkannya untuk distandarisasi dan disebarkan secara efektif kepada yang lainnya.

Pengertian yang lebih moderat dan sekaligus mengakui kedua jenis pengetahuan tersebut (tacit dan explicit) sekaligus mengakui bahwa ia merupakan kekayaan dari sebuah organisasi disampaikan oleh Scott (2000 : 6), yang mendefinisikannya sebagai the collective intellectual assets of employees. Scott menandaskan bahwa pengetahuan berbeda dengan data dan informasi. Bank-data ada di dalam server, rak, maupun tempat penyimpanan arsip lainnya. Ia tidak membuat pintar organisasi. Data hanyalah benda mati. Ia merupakan sebuah artefak. Sementara pengetahuan merupakan aset abstrak yang tersimpan di dalam benak orang-orang di dalam organisasi. Orang-orang yang berpengetahuan (knowledgable people) inilah yang membuat pintar organisasi. Mereka merupakan kekuatan utama organisasi dalam menghadapi berbagai rupa dan kecepatan perubahan di masa depan.

Barton (1995) telah menunjukkan bahwa organisasi itu adalah pengetahuan, sekaligus sebagai gudang dan sumber pengetahuan. Keahlian berkumpul dalam benak karyawan dan diwujudkan dalam mesin, perangkat lunak, dan proses rutin organisasi. Pengetahuan merupakan kemampuan inti atau strategis organisasi dalam persaingan. Ia juga menunjukkan bahwa melalui pengambilan keputusan dan tindakan sistematis, baik rutin maupun strategis, kemampuan inti dapat dibangun dan dirubah.

Untuk mengelola aset pengetahuan, diperlukan tidak hanya mengidentifikasinya tetapi juga memahaminya dalam keseluruhan kompleksitasnya. Diperlukan juga pemahaman atas peran manajer dalam mendesain organisasi bagi pembelajaran dan pembaharuan yang berkelanjutan. organisasi dapat berlangsung hidup berdasar kemampuannya beradaptasi pada saat diperlukan. Adaptasi yang berhasil tampaknya melibatkan pengarahan ulang basis keterampilan dan pengetahuan secara matang dan inkremental sehingga keahlian hari ini direka ulang menjadi kemampuan masa depan. Dalam konteks pengembangan inilah perlu dieksplorasi bagaimana mengelola pengetahuan. 
Titik awal pengelolaan pengetahuan dalam organisasi adalah pemahaman atas kemampuan inti (core capabilities). Terdapat tiga jenis kemampuan (Barton, 1995) yakni : core capabilities, yang menunjukkan keunggulan kempetitif bagi suatu organisasi. Ia harus dikembangkan sepanjang waktu dan tak dapat dengan mudah diimitasi. Ia berbeda dengan kemampuan lainnya karena mengungguli pesaingnya dalam memberikan manfaat yang berkelanjutan. Supplemental capabilities, adalah kemampuan yang menambah nilai bagi core capabilities namun masih dapat diimitasi. Enabling capabilities, kemampuan yang penting dalam kompetisi tetapi belum memadai untuk membedakannya dengan para pesaing. Kemampuan ini penting sebagai basis minimum dalam persaingan tetapi tidak mengungkapkan keunggulan kompetitif tertentu. Kemampuan menjadi inti hanya jika ia mewujudkan pengetahuannya sendiri (tidak tersedia dalam sumbersumber publik) dan unggul atas para pesaingnya.

Menurut Barton (1995) untuk menciptakan dan memelihara kemampuan inti ini, diperlukan dua hal, yakni kemampuan mengelola aktivitas mencipta pengetahuan, dan kemampuan untuk memahami dimensi kemampuan inti. Ada empat dimensi kemampuan inti yang saling tergantung, yakni : pengetahuan dan ketrampilan anggota organisasi, sistem fisik, sistem manajerial, serta nilai dan norma. Dua dimensi pertama dipandang sebagai gudang pengetahuan dinamis.

Dimensi pengetahuan dan keterampilan anggota organisasi dianggap sebagai dimensi yang paling berhubungan dengan kemampuan inti. Ia merupakan pengetahuan dan kemampuan teknologi yang terakumulasi dalam benak manusia. Terdapat tiga jenis keterampilan dan pengetahuan, yakni ilmiah (publik), spesifik industri, dan spesifik organisasi. Bergerak dari yang pertama sampai yang ketiga, jenis pengetahuan tersebut semakin sulit dikodifikasi dan ditransfer. Dalam konteks pemerintahan daerah, yang menjadi anggota organisasi tidak terbatas hanya pada pegawai birokrasi lokal saja, tetapi juga mencakup keseluruhan anggota masyarakat yang menjadi warga daerah tersebut. Pengetahuan dan keterampilan mereka inilah yang merupakan batu pondasi bagi pengembangan kemampuan inti daerah. 
Dimensi sistem fisik merupakan kemampuan yang terakumulasi dan diwujudkan dalam sistem fisik yang dikembangkan sepanjang waktu, seperti database, permesinan, dan program piranti lunak. Ia berfungsi melindungi pengetahuan seseorang yang telah pindah ke fungsi, pekerjaan, atau organisasi atau daerah lain agar tetap berada dalam sistem organisasi daerah tersebut. Ketika pengetahuan yang melekat dalam database menjadi milik daerah, maka program piranti lunak merupakan dimensi kemampuan inti yang tahan lama.

Dimensi lainnya adalah sistem manajerial yang berfungsi sebagai mekanisme penyaluran pengetahuan. Dalam dimensi ini, akumulasi pengetahuan anggota pemerintah daerah dan masyarakat setempat dibimbing dan dimonitor oleh sistem pendidikan, imbalan dan insentif organisasi. Sistem ini menciptakan saluran tentang bagaimana pengetahuan dinilai dan mengalir, selain juga menyusun halang-rintang bagi aktivitas kreasi pengetahuan yang tidak diing inkan.

Dimensi terakhir adalah nilai dan norma yang berfungsi sebagai mekanisme kendali pengetahuan. Dimensi ini menentukan jenis pengetahuan mana yang diperhatikan dan dibudayakan, dan jenis aktivitas kreasi pengetahuan mana yang ditolerir dan didukung. Ada sistem kasta dan status, ritual perilaku, dan kepercayaan yang dihubungkan dengan berbagai jenis pengetahuan dan teknologi yang sama kaku dan kompleksnya dengan agama. Keterampilan dan pengetahuan, baik yang melekat di benak manusia maupun yang melekat dalam sistem fisik dan sistem manajerial, menunjukkan karakter tertentu yang bergantung pada apa yang dinilai di dalam organisasi. Nilai dan norma ini setara dengan konsep nilai dan asumsi sebagaimana dijelaskan oleh Schein (1984). Budaya daerah jelas memiliki hubungan rumit dengan jenis pengetahuan yang dikehendaki dan yang tidak serta termanifestasi pula dengan dimensi pengetahuan lainnya.

\section{Aktivitas Kreasi Pengetahuan}

Kemampuan inti beserta segenap dimensinya di atas bukan sesuatu yang dapat terjadi dengan sendirinya. Ia membutuhkan aktivitas tertentu untuk membentuk dan memeliharanya. Hubungan antara aktivitas tersebut dengan 
kemampuan inti adalah : kemampuan inti dikreasi melalui knowledge-creating activities, dan aktivitas tersebut bergantung dan diberdayakan oleh kemampuan inti. Terdapat empat aktivitas, yakni : pemecahan masalah bersama, integrasi alat dan metodologi baru, eksperimen dan penyusunan prototipe, penyerapan pengetahuan baik yang berasal dari luar organisasi maupun dari pasar (Barton, 1995).

Meningkatnya kompleksitas masalah, proliferasi spesialisasi pendidikan formal, dan langkah globalisasi membutuhkan aktivitas pemecahan masalah dalam pengembangan produk baru secara bersama melampaui batas disiplin, kognisi, geografis, dan budaya. Tiga sumber perbedaan individual dalam pemecahan masalah adalah spesialisasi, gaya kognisi yang disukai (preferred cognitive style), dan preferensi alat dan metodologi. Tiga sumber keragaman intelektual ini dapat meningkatkan pemecahbelahan dan membuat rintangan bagi pemecahan masalah bersama. Namun, ketiganya juga dapat memberikan peluang kreativitas yang sangat besar.

Dalam pemecahan masalah, pola yang pergunakan oleh orang yang paling intelek sekalipun dapat dibatasi oleh pengalaman dan keberhasilan sebelumnya. Orang dapat jatuh ke dalam kebiasaan pikiran sehingga merintangi pemecahan masalah inovatif yang mudah dan cepat bahkan untuk hal-hal kecil sekalipun. Dengan demikian, orang ini ada dalam mind-set trap, yakni kemanfaatan yang sangat tinggi dalam aktivitas rutin. Jika demikian halnya, maka pemecahan masalah menjadi terbatas sehingga mudah bagi organisasi menjadi disfungsional bahkan terjebak dalam kekakuan inti.

Keterbatasan dalam respons pemecahan masalah dalam suatu organisasi bermula dari individu. Orang seringkali menjadi sangat terampil dalam menerapkan solusi tertentu atas masalah, bahkan ia menjadi terikat secara emosional dengan mind-setnya. Situasi ini disebut sebagai Signature Skills. Ia merupakan kemampuan seseorang yang cenderung mengidentifikasi dirinya secara profesional. Ia merupakan ekspresi interaktif dari tiga preferensi yang saling terkait, yakni preferred task, preferred cognitive approach, preferred technology. 
Untuk mengatasi masalah ini adalah dengan mengakui potensi yang melekat dalam signature skills yang bertentangan. Creative abrasion menyalurkan energi yang muncul dari pertentangan tersebut menjadi kreasi daripada perusakan, menjadi sintesis daripada fragmentasi. Manajer perlu mengembangkan atmosfer yang mendukung orang-orang untuk menghargai sudut pandang orang lain tanpa selalu menyetujuinya. Dalam lingkungan ini, orang dapat menerima keragaman kognisi tanpa menimbulkan perpecahan.

Creative abrasion tidak sama dengan perayaan keragaman atas dasar jender, preferensi seksual, maupun latar belakang etnis. Ia juga tidak identik dengan konfrontasi konstruktif. Ia juga bukanlah konfrontasi dan pelanggaran pribadi. Creative abrasion melibatkan perhatian yang lebih khusus terhadap pendekatan kognitif orang-orang terhadap pemecahan masalah dan inovasi. Ia merupakan satu bentuk dari konfrontasi konstruktif, yang bertujuan untuk mendukung inovasi dan memberdayakan integrasi kerangka masalah dan pendekatan pemecahan masalah yang berbeda. Menghadapi persoalan ini, manajer seyogyanya menyusun prasyarat yang memberdayakan keragaman spesialisasi, gaya kognisi, dan metodologi yang mengarah pada creative abrasion.

Berkenaan dengan hal ini, seyogyanya pemerintah daerah dan masyarakat di daerah tidak menghindari masalah dan selalu mencari kambing hitam atas masalah yang terjadi dalam manajemen keuangan daerah. Alangkah baiknya jika masalah dihadapi bersama serta dicari jalan pemecahannya. Proses menyadari, menganalisis, dan menghadapi masalah merupakan sarana yang sangat baik bagi setiap orang untuk belajar dan meningkatkan kemampuannya dalam memecahkan masalah. Kebiasaan dan keterampilan dalam mengatasi masalah saat ini akan menimbulkan ide, kreativitas, dan akumulasi pengalaman yang bermanfaat untuk menghadapi masalah yang senantiasa muncul dan berkembang di masa depan. 


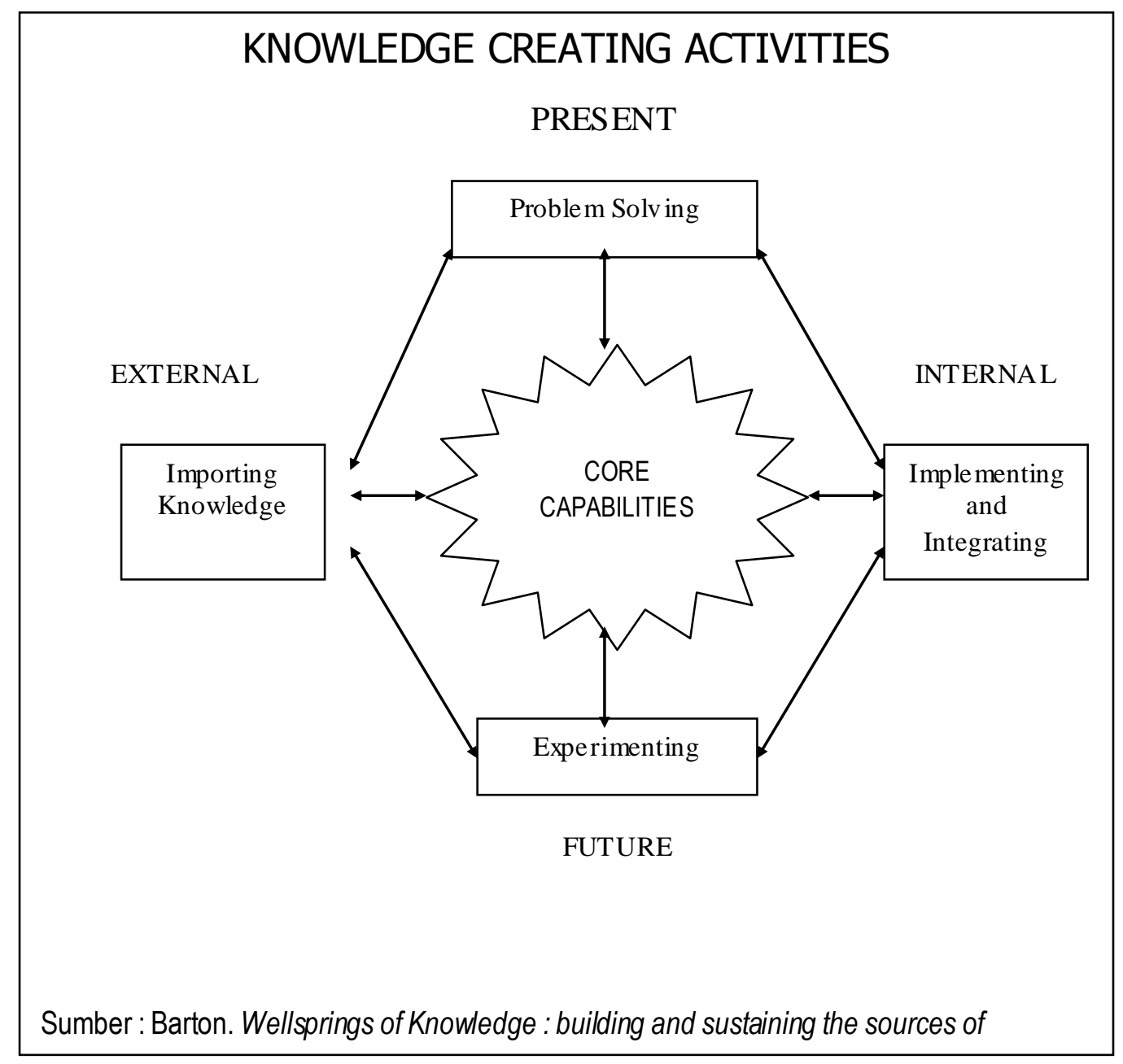

Masalah-masalah manajemen keuangan daerah yang ada saat ini seyogyanya diakui dan bukannya mati-matian disangkal sembari menyembunyikan persoalan yang lebih besar di masa depan. Masalah ini sebaiknya dianggap sebagai peluang ancang-ancang untuk secara bertahap meningkatkan kemampuan daerah hingga mampu menggapai kemampuan inti. Bila kemampuan inti telah tercapai maka sulit bagi produk atau daerah lain menyaingi kemampuan yang dimiliki. Kemampuan ini bahkan akan dapat membantu daerah untuk tetap bertahan bahkan berkembang dalam globalisasi. 
Implementasi dan integrasi proses dan alat baru harus dilihat sebagai tindakan inovasi ketimbang semata sebagai pelaksanaan suatu rencana. Integrasi dari alat dan proses yang tersedia di pasar terbuka dapat menjadi keunggulan kompetitif. Selain kualitas dan biaya teknologi, serta kesesuaiannya dengan lingkungan pengguna, ada dua proses manajerial penting yang dapat menjelaskan derajat dan jenis yang berbeda dari implementasi yang berhasil, yakni keterlibatan pengguna (user involvement), dan adaptasi bersama (mutual adaptation).

Terdapat dua alasan untuk melibatkan pengguna dalam pengembangan sistem teknik baru. Pertama, implementasi berdampak pada perubahan dalam pekerjaan pengguna, dan penelitian menyarankan bahwa orang lebih menerima ketika ia memberi andil terhadap desainnya. Kedua, melibatkan pengguna dalam desain alat menghasilkan desain unggul karena pengguna memiliki pengetahuan khusus mengenai lingkungan dimana alat tersebut akan diper-gunakan, dan pengetahuan itu seharusnya diwujudkan dalam desain.

Ada dua motif utama dalam pelibatan pengguna ini. Pertama menciptakan kongsi (buy-in) dalam proses implementasi, yang berarti adanya penerimaan atas perubahan alat baru. Kedua, mewujudkan pengetahuan (embodying knowledge) karena pengembang tidak memiliki semua pengetahuan yang diperlukan sehingga ia harus berinteraksi dengan pengguna untuk menciptakan, atau menangkap dan menstruktur, lalu mewujudkan pengetahuan tersebut. Pengembang alat memahami prinsip dan pengetahuan ilmiah yang mendasari alat proses baru. Pengguna yang sangat terampil akan memahami proses kerjanya sendiri sehingga menjadi sumber keterampilan yang dibutuhkan untuk memahami bagaimana alat baru bekerja di lapangan.

Untuk mewujudkan pengetahuan ini dalam inovasi, pertama harus dipahami dulu manfaat dari keterlibatan pengguna ini. Keterlibatan ini bisa berentang dari negatif sampai positif. Ada yang mengungkapkan bahwa keterlibatan ini hanya bisa berhasil dengan melakukan pemilihan pengguna yang dilibatkan berdasarkan kriteria tertentu terutama keahliannya dalam menjalankan tugas. Membedakan bentuk-bentuk keahlian juga merupakan hal penting sehingga dapat dengan tepat memperoleh pengguna ahli yang sesuai dengan pengembangan 
alat yang direncanakan. Isu berikutnya adalah aspek keterwakilan dari pengguna ahli tersebut sehingga masukan-masukan yang diperoleh dapat mewakili situasi, kondisi, dan kebutuhan pengguna yang sebenarnya. Aspek lainnya adalah kemauan pengguna untuk berpartisipasi baik dalam memberikan umpan balik maupun saran.

Keterlibatan pengguna ini merupakan istilah yang sangat luas mencakup banyak interaksi yang memungkinkan. Terdapat empat jenis keterlibatan pengguna ini, yakni, delivery, consultancy, codevelopment dan apprenticeship.

Mutual adaptation adalah penemuan kembali teknologi untuk menyesuaikannya dengan lingkungan kerja dan adaptasi simultan organisasi untuk menggunakan sistem teknik baru. Dua aspek utama dari mutual adaptation adalah : ia terjadi dalam spiral perubahan berulang-ulang baik dalam skala kecil maupun besar; dan ia memerlukan perhatian terhadap empat dimensi kemampuan. Spiral dan bukannya siklus menunjuk pada keputusan yang dipertimbangkan ulang tak pernah sama dengan yang pernah dibuat karena konteks keputusannya selalu berubah. Spiral adaptasi berbeda besaran gelombangnya. Gelombang kecil menuntut perbaikan peran atau tugas tertentu saja, sementara gelombang besar memerlukan perubahan strategis dalam organisasi.

Usaha ekstra memang diperlukan untuk mengelola implementasi dan pembelajaran. Untuk memerangi kegagalan eksperimen implementasi dan integrasi, pimpinan daerah dapat melakukan dua hal, yakni jalani terus perubahan sejauh memungkinkan, dan rayakan keberhasilan kecil yang dapat dicapai. Hal tersebut akan meningkatkan energi perubahan dan memelihara harga diri karyawan dalam menghadapi perubahan.

Bagi daerah, aktivitas ini bukanlah sekedar tugas rutin alamiah, tetapi lebih berupa proses pembelajaran untuk meningkatkan kemampuan yang bergulir di daerah. Pada akhirnya penyerapan dan penyebarannya mampu mengembangkan perputaran pengetahuan di daerah tersebut sehingga potensi inovasi dapat berkembang dengan baik. Dengan kesadaran seperti ini, maka pengeluaran daerah bisa ditujukan untuk maksud ini sehingga kemanfaatan pengeluaran daerah dirasakan pada dua hal, yakni : dalam jangka pendek ia mampu memecahkan 
masalah, dan dalam jangka panjang ia membangun kemampuan inti daerah untuk bersaing dan mandiri. Pengeluaran untuk keperluan ini jelas dapat dianggap sebagai capital expenditure.

Sebenarnya otoritas daerah memahami benar bahwa setiap keputusan yang mereka ambil hari ini akan mempengaruhi kemampuan organisasi untuk bersaing dan mandiri di masa depan. Perencanaan strategis biasanya dipuji sebagai pelaksanaan penting yang mengarahkan keputusan tersebut. Secara tradisional, pelaksanaan perencanaan menekankan pada penyusunan tujuan akhir yang sangat spesifik dan menyusun deskripsi rinci atas langkah-langkah pencapaiannya. Namun demikian, rencana strategis rinci dapat menjadi usang setelah ia disetujui, dan membuatnya tak berguna sebagai petunjuk dan mungkin justru membahayakan. Kemampuan inti saat ini bisa beralih menjadi kekakuan inti di masa mendatang.

Aktivitas eksperimen dan penyusunan prototipe memunculkan dua jenis kemampuan baru. Pertama, eksperimen menciptakan apa yang disebut varietas yang diperlukan dalam produk dan proses. Kedua, tindakan eksperimen menyusun suatu virtuous cycle of innovation; siklus ini bisa menjadi karakter dominan daerah bahwa kemampuan bereksperimen dan menyusun prototipe secara efisien dan kompeten dengan sendirinya menjadi kemampuan unggul dalam bersaing.

Terdapat dua formula untuk menciptakan arahan strategi baru, yakni : great leader formula (top down), ketika otoritas puncak di daerah menempa proyek yang dimaksudkan untuk mendukung arahan strategis baru (strategic intent) sebagai satu-satunya cara yang mereka lihat untuk mengatasi kekakuan inti; dan hands-on champion formula (bottom up), yang berarti arahan teknologi baru berasal dari strategic improvisation, yang berarti bahwa proyek dapat mengubah arahan strategis organisasi atau memulai pertumbuhan kemampuan teknologi yang sama sekali baru.

Agar gagasan eksperimen, baik secara top-down maupun bottom-up, menentukan masa depan, para pejabat daerah mempunyai tugas untuk memfasilitasinya dengan menciptakan iklim organisasi yang menerima dan mendukung aktivitas tersebut. Caranya adalah dengan : 1. memisahkan kegagalan 
cerdas (intelligent failure) dengan kegagalan tak perlu lainnya; 2. mengakui peran kegagalan dalam membangun pengetahuan. Tugas lainnya adalah dengan menempa terus menerus praktek eksperimen dan pembuatan prototipe. Semakin banyak praktek maka semakin baik hasilnya. Praktek ini melibatkan eksperimentasi, pembuatan protipe, internal wrecking crews, dan pembuatan prototipe organisasi.

Implementasi dari gagasan eksperimen dan penyusunan prototipe ini dapat dilaksanakan oleh pemerintah daerah dengan melakukan dua hal. Pertama membentuk lembaga penelitian dan pengembangan yang sesuai dengan kebutuhan daerah. Lembaga ini seyogyanya didukung oleh orang-orang yang berkompeten di bidangnya dan dibiayai dari APBD atau dengan cara lainnya. Jika pemerintah daerah tidak dapat menggunakan cara ini, maka dapat pula mendorong iklim eksperimentasi yang kondusif di daerah tersebut sehingga masyarakat bisa melakukan proses pembelajarannya sendiri serta memecahkan masalahnya sendiri. Apakah pemerintah daerah akan berperan aktif sebagai operator atau berperan memberdayakan masyarakat bergantung pada model pemerintahan daerah yang dianut. Baik proses maupun hasil dari eksperimen dan penyusunan prototipe ini jelas merupakan pengetahuan yang berharga bagi aparat dan masyarakat di daerah tersebut.

Sangat sedikit, kalaupun ada, organisasi atau daerah yang mampu membangun kemampuan intinya tanpa menyerap pengetahuan dari luar batas yurisdiksinya. Untuk itu, menyerap pengetahuan dari luar merupakan aktivitas manajerial penting seperti halnya mengintegrasi batas internal. Kemampuan daerah untuk mengenali nilai informasi baru dari luar, lalu mengasimilasi dan menerapkannya menjadi sasaran komersial dan layanan sangatlah penting bagi kemampuan inovasinya.

Namun demikian, tidak semua aliansi pengembangan kemampuan menawarkan peluang yang sama dalam mengimpor pengetahuan. Supply alliances dibentuk untuk meminimalkan biaya transaksi perdagangan dan pertukaran produk. Positioning alliances merupakan bagian strategi pemasaran yang membantu daerah menciptakan atau menyelesaikan rintangan dalam me masuki 
pasar. Learning alliances sejak awal dimaksudkan untuk memperbesar pengetahuan internal. Dengan demikian, untuk kepentingan mengimpor pengetahuan maka aliansi yang tepat adalah jenis yang terakhir tersebut.

Organisasi berusaha memperoleh pengetahuan dari sumber luar jika menghadapi capability gap, yakni ketika keahlian teknis penting dan strategis tidak lagi tersedia atau memadai secara internal. Untuk mengidentifikasi kesenjangan kemampuan ini, maka manajer harus memahami hubungan antara strategi dengan teknologi, lalu menilai derajat familiaritas dengan teknologi yang ada saat ini di dalam organisasi. Terdapat beberapa sebab yang memicu capability gap ini, yakni menurunnya penelitian dasar dalam industri, kematangan dan keusangan teknologi, serta peluang fusi teknologi yang terbatas.

Sumber-sumber eksternal untuk mengimpor teknologi bisa berasal dari berbagai pihak, yakni konsultan, konsumen, laboratorium nasional, vendors, universitas, dan perusahaan lain baik pesaing maupun bukan. Transfer pengetahuan melintasi batas daerah lebih mudah jika stakeholdernya bukan pesaing langsung. Salah satu sumber pengetahuan potensial adalah pasar yang merupakan sumber pengetahuan yang tak kalah pentingnya yang berada di luar atau di dalam batas daerah. Meskipun pengembangan produk dilakukan di dalam organisasi, tetapi keberhasilannya ditentukan oleh penerimaan konsumen, warga atau pasar. Banyak inovasi menemui kegagalan ketika diluncurkan di pasar. Arus pengetahuan dari pasar mengubah informasi ilmiah menjadi produk dan jasa komersial. Terdapat beberapa langkah untuk belajar dari pasar, pertama mengenali situasi definisi produk atau layanan baru, kedua, mengetahui cara menyerap pengetahuan dari pasar, dan yang ketiga, menggunakan model untuk menyusun bersama konsep produk.

Bagi pemerintah daerah, penting sekali untuk memahami dan menyerap pengetahuan yang berada di konsumen internalnya (warga) atau konsumen eksternalnya yang berada di luar daerah. warga adalah konsumen yang menik mati secara langsung atau tidak beragam bentuk penyediaan barang dan jasa publik yang dilakukan sendiri oleh pemerintah daerah atau dicontracting-outkan. Pasar merupakan konsumen dari produk atau layanan yang dihasilkan oleh daerah 
tersebut. Pasar ini jelas berada di luar batas yurisdiksi daerah tersebut. secara umum, baik warga ataupun pasar mempunyai potensi tertentu yang berkaitan dengan pendapatan dan pengeluaran daerah baik secara langsung ataupun tidak.

Warga dan pasar ini memiliki pengetahuan tersendiri yang apabila ditelaah dengan baik akan membantu daerah untuk mengembangkan kemampuannya dalam memenangkan persaingan. Interaksi berkelanjutan akan meningkatkan daya serap pengetahuan yang beredar di daerah, mengembangkan kemampuan inti, dan memperkuat kemandirian daerah. Jika manajemen keuangan daerah didesain untuk membiayai aktivitas penciptaan pengetahuan ini maka pemasukan yang akan diterima melalui inovasi produk dan layanan publik dan yang dihasilkan oleh masyarakat akan meningkatkan pendapatan daerah secara berkelanjutan. Kemampuan inti akan menghasilkan produk dan layanan yang dikembangkan daerah tersebut akan memiliki daya saing tinggi yang tidak dapat dengan mudah diimitasi oleh para pesaingnya.

Empat aktivitas kreasi pengetahuan di atas sebenarnya mengajak dan melibatkan segenap komponen anggota masyarakat di daerah untuk belajar mengatasi masalah mereka sendiri. Kemampuan dan kemauan mereka untuk belajar jelas merupakan prasyarat mutlak untuk mendukung keberhasilan empat aktivitas tersebut. Konsep pembelajaran masyarakat merupakan hal yang tak boleh dilupakan karena ia tidak hanya memperkokoh pondasi pengetahuan mereka tetapi juga mengembangkan pengetahuan tersebut. Dengan demikian, bila proses ini dilaksanakan maka masyarakat di daerah akan menikmati kemandirian, inovasi dan keunggulan bersaing, serta kemampuan dalam memenuhi kebutuhan dan layanan publiknya sendiri.

\section{PENUTUP}

Pada dasarnya manajemen keuangan daerah yang mandiri berasal dari desentralisasi fiskal yang dilimpahkan kewenangannya oleh pemerintah pusat sebagai bagian yang dibutuhkan bagi desentralisasi politik. Manajemen keuangan daerah akan menyangkut dua hal pokok, yakni pendapatan dan pengeluaran. Terdapat beberapa masalah yang dihadapi daerah dalam mengelola keuangannya. 
Pertama, masalah yang berkaitan dengan pendapatan, yakni kecenderungan ketergantungan pada pemerintah pusat, pungutan dan pengenaan pajak yang serampangan, dan ketergantungan yang berlebih pada pendapatan dari eksplorasi sumber daya alam. Kedua, masalah yang berkaitan dengan pengeluaran. Masalah ini berkisar pada pemborosan struktural, baik karena struktur birokrasi yang tidak efisien dan tidak jelas manfaatnya, maupun karena pemanfaatan dana yang tidak efektif bagi program tertentu. Masalah lainnya berkisar pada pemborosan behavioral yang bersumber pada perilaku menyimpang, korup, dan pelanggaran kekuasaan dari para pejabat daerah. secara keseluruhan masalah di atas kontraproduktif dan berbahaya bagi kelangsungan kemandirian daerah serta merugikan pelayanan publik yang seharusnya menjadi lebih baik diterima publik melalui kebijakan desentralisasi.

Untuk mengatasi persoalan ini dan meningkatkan kadar kemandirian daerah di masa mendatang, maka seyogyanya daerah berpaling pada pendekatan resource-based, yakni sebuah pendekatan yang mendasarkan diri pada kekuatan dan potensi internal untuk memenangkan persaingan. Kini, pendekatan sumber daya ini berkembang melalui very intangible resource, yakni pengetahuan, sebagai suatu kekuatan utama yang seharusnya dijelajahi, diasah, dan dikembangkan oleh suatu organisasi. Kemampuan mengelola pengetahuan ini akan memunculkan kemampuan inovasi bagi organisasi tersebut. Inovasi inilah yang pada saat ini diyakini sebagai sumber bagi keunggulan bersaing.

Kemampuan mengelola pengetahuan dan memunculkan inovasi yang tidak dapat ditiru dengan mudah oleh para pesaing merupakan kemampuan inti sebuah organisasi. Jika sebuah daerah mampu mengelola pengetahuan sehingga memiliki kemampuan inti, maka daerah tersebut diyakini akan mampu menyelesaikan persoalannya dan mampu menciptakan keunggulan bersaing. Dengan demikian, tentu pelayanan publik yang diterima oleh masyarakat akan semakin memuaskan dan kemandirian daerah dalam mengelola masalah dan kebutuhannya sendiri akan terpenuhi. Kemampuan inti melekat dalam empat dimensi yang saling bergantung, yakni pengetahuan dan ketrampilan seluruh komponen anggota masyarakat daerah, sistem fisik yang ada dan dikembangkan daerah tersebut, sistem 
manajerial (local self governance), dan nilai dan norma yang berlaku. Kemampuan inti ini dapat dicapai melalui empat ektivitas, yakni pemecahan masalah, implementasi dan integrasi proses dan alat baru, eksperimen, dan penyerapan pengetahuan dari luar daerah atau pasar.

\section{DAFTAR PUSTAKA}

Barton, D. L. 1995. Wellsprings of knowledge : building and sustaining the sources of innovation. Boston : Harvard Business School Press.

Buckley, P.J., \& Carter, M.J. 2000. "Knowledge management in global technology markets : applying theory to practice". Long Range Planning, Vol. 33.

Fiscal Policy Resource Center, 2001. "An introductory overview of intergovernmental fiscal relations" dalam Principles of Fiscal Decentralization. Atlanta : the Andrew Young School of Policy Studies, Georgia State University.

Hamel, G., Prahalad, C.K. 1994. Competing for the Future. Massachusetts : Harvard Business School Press.

Hardin, G. 1968. "The tragedy of the commons", dalam Science $162: 1243-8$.

Humes IV, S. 1991. Local governance and national power : a worldwide comparison of tradition and change in local government. New York : Harvester.

Huseini, M. 1999. "Mencermati misteri globalisasi : menata-ulang strategi pemasaran internasional Indonesia melalui pendekatan resource-based". Pidato Pengukuhan Guru Besar UI, 25 September.

Mackintosh, M., \& Roy, R. 1999. "Introduction : economic decentralization, issues of theory and policy" dalam Mackintosh, M., \& Roy, R. Economic decentralization and public management reform. Cheltenham : Edwar Elgar.

Manor, J. 1999. The Political Economy of Democratic Decentralization. Washington : The World Bank.

Nonaka, I. \& Takeuchi, H. 1995. The knowledge-creating company : how Japanese companies create the dynamics of innovation. New York : Oxford University Press.

Nonaka, I., Toyama, R., \& Konno, N. 2000. "SECI, $b a$, and leadership : a unified model of dynamic knowledge creation". Long Range Planning, Vol. 33.

Norton, A. 1994. International Handbook of Local and Regional Government : A Comparative Analysis of Advanced Democracies. Cheltenham : Edwar Elgar. 
Ostrom, E. 1990. Governing the commons : the evolution of institutions for collective action. Cambridge : Cambridge University Press.

Schein, E. H. 1984. Organizational culture and leadership. San Francisco : Jossey-Bass publishers.

Scott, M.C. 2000. Reinspiring the corporation : the seven seminal path to corporate greatness. Chichester : John Wiley \& Sons, Ltd.

Smith, B.C. 1985. Decentralization : the territorial dimension of the state. London : George Allen Unwin.

Zolingen, S.J. van, Streumer, J.N., Stooker, M. 2001. "Problems in knowledge management : a case study of a knowledge-intensive company". International Journal of Training and Development $(5: 3)$.

*) Dr. M.R. Khairul Muluk, M.Si., Dosen Fakultas Ilmu Administrasi Unibraw 